\title{
Formation of Polymeric Assemblies of Six-Coordinate Metal Complexes with Mixed Bridges of Dicarboxylato-Azido
}

\author{
Riyadh M. Ahmed, Taki A. Himdan, Ahmed T. Numan and Mohamad J. Al-Jeboori' \\ Department of Chemistry, College of Education, Ibn Al-Haitham, University of Baghdad, \\ P.O.Box $\leqslant 10 \cdot$, Adhamiya Baghdad-Iraq. \\ 'E-mail: mohamadaljeboori@yahoo.com.
}

\begin{abstract}
New polydentate ligand namely bis(N-carboxylatoethyl)- $\_, \varsigma_{-}$-dipyridinium) L was synthesised from the reaction of $\varepsilon, \S$-dipyridine with ethyl chloropropionate. Polymeric complexes of general formulae $[\mathrm{Cr} r(\mathrm{~L})(\mathrm{Nr} r) \varepsilon] \mathrm{Cl} r . \mathrm{HrO}, \operatorname{Nar}\left[\mathrm{Ag} r(\mathrm{~L})\left(\mathrm{N}_{r}\right) \varepsilon\right] . \mathrm{HrO}$ and $\left[\mathrm{Mr}(\mathrm{L})\left(\mathrm{N}_{r}\right) \varepsilon\right] . n H_{r} \mathrm{O}$, where $(\mathrm{M}=$ $\mathrm{Mn}(\mathrm{II}), \mathrm{Fe}(\mathrm{II}), \mathrm{Co}(\mathrm{II}), \mathrm{Ni}(\mathrm{II}), \mathrm{Cu}(\mathrm{II}), \mathrm{Zn}(\mathrm{II})$ and $\mathrm{Cd}(\mathrm{II})$; (where $\mathrm{n}=\mathrm{r}^{\prime}$; ; ; ; ; ; ’ and ', respectively)) are reported. The mode of bonding and overall geometry of the complexes were determined through physico-chemical and spectroscopic methods. These studies revealed octahedral geometry complexes. Molecular structure for the complexes has been optimised by CS Chem rD Ultra Molecular Modelling and Analysis Program and supported a six coordinate geometry.
\end{abstract}

Keywords: Polymeric complexes; Bridged zido-carboxylato ligands; Bis (N-carboxylatoethyl) \&,ะ`dipyridinium); Structural study, theoretical treatment.

\section{Introduction}

Coordination polymers chemistry based on organic-metal framework is an interested hot topic in the synthetic inorganic chemistry, and recently a range of these compounds using different synthetic approaches have been reported [1]. These interested materials shown a range of applications includes light harvesting and magnetic properties. The design and synthesis of magnetic coordination polymers with peculiar structure and potential application have become a focus of intense research activities in the fields of coordination and material chemistry [r]. The key to designing such material is based on the type of the bridging ligand that can effectively mediate the magnetic interactions and construct novel structures [ $\left.{ }^{\kappa}\right]$. Several parameters are influenced the self-assembly of coordination polymers. These include: medium; $\mathrm{pH}$; temperature; the nature of metal ions; coordination geometry; stereochemistry; and number of coordination donors provided by ligands [₹]. Synthesis and fabrication of electro-conductive materials has been a great challenge in coordination polymers $\left[{ }^{\circ}\right]$. These polymers show a range of applications and can be used as optoelectronic devices such as electroluminescent devices, thin-film transistors, and solar cells[ $\left.{ }^{\top}\right]$. Metal complexes with bridging azido moiety have provided unique structures and magnetic properties. Furthermore, the carboxylate group can also efficiently transmit magnetic exchange. Therefore, combining azide and carboxylate moieties in one system is an interesting approach for constructing new materials and modulating magnetic behaviours. The employment of neutral dicarboxylates as ligands and/or combining to Ł, has the potential coordination sites involving both nitrogen of dipyridine and the carboxylate oxygen $[\mathrm{V}]$. It can coordinate in a variety of coordination modes [^], and provide several possibilities in creating supramolecular architectures through hydrogen bonds and $\pi-\pi$ interactions; it has been widely used to synthesise mononuclear, dinuclear, trinuclear, and coordination polymeric compounds.

\section{Experimental}

\section{Materials and Methods}

All reagents were obtained commercially (Aldrich) and used without further purification. Solvents used in the synthesis were distilled from appropriate drying agent immediately prior to use.

\section{Physical Measurements}

Elemental analyses $(\mathrm{C}, \mathrm{H}$ and $\mathrm{N})$ were carried out on a Heraeus instrument (Vario EL). IR spectra were recorded as $\mathrm{KBr}$ discs using a Shimadzu $\wedge \_\ldots \quad S$ FTIR 
spectrophotometer from $\varepsilon \cdots-\cdots, \cdots \mathrm{cm}^{-1}$. Melting points were obtained on a Electro-thermal Stuart melting point SMP capillary melting point apparatus and are uncorrected. Electronic spectra were measured from $r \cdots-11 \cdots \mathrm{nm}$ for $1^{-r} \mathrm{M}$ solutions in DMSO at ${ }^{\circ}{ }^{\circ} \mathrm{C}$ using a Shimadzu $1 \wedge .$. spectrophotometer. ' $\mathrm{H}-{ }^{\top T} \mathrm{C}-\mathrm{NMR}$ spectra were acquired in DMSO-dr solution using a Jeol ¿.. MHz spectrometer with tetramethylsilane (TMS) as an internal standard for ' $\mathrm{H}$ NMR analysis. Mass spectra for ligand and some metal complexes were obtained by positive Electron-Impact (EI), accurate Electrospray (ES) and Matrix Assisted Laser Desorption Ionisation Time of Flight MS (MALDITOF MS) was recorded on a VG autospec micro mass spectrometer on BRUKER DALTONICS. The spectra were recorded at the EPSRC Swansea Mass Spectroscopy Facility, U.K. Metals were determined using a Shimadzu (A.A) $\uparrow \wedge \cdot G$ atomic absorption spectrophotometer. Chloride content was determined using potentiometer titration method on a $7 \wedge$ T-Titrp processor-7 70 DosimatMetrohm Swiss. Conductivity measurements were made with DMSO solutions using a PW $90 Y 7$ digital conductivity meter and room temperature magnetic moments were measured with a magnetic susceptibility balance (Johnson Matthey Catalytic Systems Division).

\section{Synthesis}

\section{Preparation of the ligand}

The preparation of the ligand was adopted according to a published method $\left[{ }^{\wedge}\right]$ and as follows:

A solution of ethyl chloropropionate $(r, 0) \mathrm{g}, r \cdot \mathrm{mmol})$ was added slowly to a mixture of $\Sigma, \Sigma$-bipyridine $(r \mathrm{~g}, 1 \cdot \mathrm{mmol})$ dissolved in acetone ( $r^{\circ} \mathrm{mL}$ ). The resulting solution was allowed to reflux for $V^{r} \mathrm{~h}$. After the acetone was removed under reduced pressure a green residue was left, and then a mixture of $\mathrm{HCl}(\bullet \cdot \mathrm{mL}, \diamond \% \mathrm{w} / \mathrm{v})$ was added. The resulting mixture was heated under reflux for $r \leqslant h$ to give a yellow solution. Removal of solvent afforded a pale yellow powdery product; yield ( $r, r \leqslant \mathrm{~g}, 0 \wedge \%)$. The product was then dissolved in $(0 \cdot \mathrm{mL})$ of water, and silver (I) oxide $(1,0 \mathrm{~g}, \cdot, \ldots 70 \mathrm{mmol})$ was added, with stirring, to remove chloride ions.
The white precipitate was filtered off, and the filtrate was then dried to yield a pale yellow solid, which was recrystallised from water/ethanol $(1: \varepsilon, \mathrm{v} / \mathrm{v})$ to give ligand (L) as a yellow solid; yield $(1, \mathrm{~V} \cdot \mathrm{g}, \leqslant \leqslant \%)$, m.p. $=r \leqslant r{ }^{\circ} \mathrm{C}$. 'H NMR data $(\mathrm{ppm}), \delta_{\mathrm{H}}(\varepsilon \cdots$ MHz, DMSO-dr): shows signals at $r, r_{-}, r, r$ $\left(₹ \mathrm{H}, \mathrm{t}, \mathrm{C} r, r^{-}-H\right)$, This signal is shifted to upfield due the attachment to electron withdrawing group, and therefore the $\left(-\mathrm{CH}_{r}\right)$ group is shielded and appeared at lower chemical shift, $\varepsilon, V_{-} \varepsilon, V Y(\varepsilon \mathrm{H}, \mathrm{t}, J=\tau, \wedge \cdot \mathrm{Hz}$, $\left.\mathrm{C} r, r^{-}-H\right)$, This peak is shifted to downfield due to its attachment to the nitrogen atom, electron withdrawing group, and therefore the $\left(-\mathrm{CH}_{r}\right)$ group is deshielded and appeared at higher chemical shift, $\wedge, \uparrow \cdot-\wedge, \uparrow r(\leqslant \mathrm{H}, \mathrm{d}$,

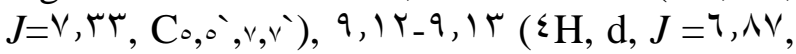
$\left.\mathrm{C} \varepsilon, \Sigma^{\wedge}, \wedge, \wedge^{\prime}\right) .{ }^{\top} \mathrm{C}$ NMR: shows chemical shift at

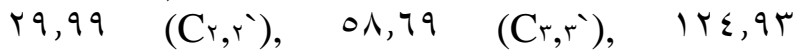

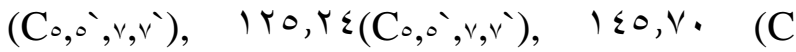

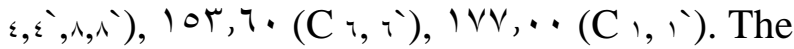
positive ES mass spectrum of the ligand showed the following fragments; $r \cdot 1(0 \%) \mathrm{M}^{+}$, corresponding to $\mathrm{C}_{\uparrow} \mathrm{H} \mathrm{H}_{\uparrow} \mathrm{NrO}_{r}$, rov (rr \%) [M-

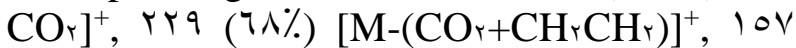
(..$\%)$ [M-(-(CO- $\left.\left.{ }_{r}+\mathrm{CH}_{r} \mathrm{CH}_{r}+\mathrm{CH}_{r} \mathrm{CH}_{r} \mathrm{CO}_{r}\right)\right]^{+}$, respectively.

\section{General synthesis of polymeric complexes with ligand}

A mixture of metal chloride $(\cdot, \leqslant 9 \mathrm{mmol})$ $(\cdot, 1), \cdot, \cdot 9, \cdot, \cdot 9, \cdot, 11, \cdot, 11, \cdot, \cdot 1, \cdot, \cdot 7$, $\cdot, 11$ and $\cdot, \cdot \wedge \mathrm{g}), \mathrm{L}(\cdot, \leqslant 9 \mathrm{mmol})(\cdot, 10 \mathrm{~g})$, and $\mathrm{NaNr}(\cdot, 99 \mathrm{mmol})(\cdot, \cdot 7 \leq \mathrm{g})$ in water/ethanol $(0 . \mathrm{mL}, \varepsilon: \tau \mathrm{v} / \mathrm{v})$ was stirred for $r \cdot \mathrm{min}$ at room temperature, then the mixture was refluxed for $r \cdot \min$. Slow evaporation of the solution at room temperature yielded green crystals of $\mathrm{Cr}$ (III) complex within two weeks, washed with $\left({ }^{\circ} \mathrm{mL}\right)$ of diethyl ether, and then

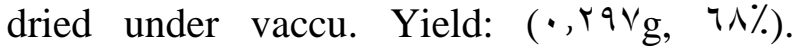
Elemental analysis data, colours, and yields for the complexes are given in Table (1). 
Table (')

Colours, yields, elemental analyses, and molar conductance values.

\begin{tabular}{|c|c|c|c|c|c|c|c|c|c|}
\hline \multirow{2}{*}{ Formula } & \multirow{2}{*}{ Colour } & \multirow{2}{*}{$\begin{array}{c}\mathrm{M} . P \\
{ }^{\circ} \mathrm{C} \\
\end{array}$} & \multirow{2}{*}{$\begin{array}{c}\text { M.W } \\
\text { gmole }^{-1}\end{array}$} & \multirow{2}{*}{$\begin{array}{c}\text { Yield } \\
\% \\
\end{array}$} & \multicolumn{5}{|c|}{ Micro analysis found (calc)\% } \\
\hline & & & & & $C$ & $H$ & $N$ & Metal & $\mathrm{Cl}$ \\
\hline $\mathrm{C}_{\uparrow} \mathrm{H}_{\curlywedge \wedge} \mathrm{Cl}_{\uparrow} \mathrm{Cr}_{\uparrow} \mathrm{N}_{\curlywedge} \leqslant \mathrm{O} 。$ & Green & $\begin{array}{l}\text { Dec } \\
r \leqslant 7\end{array}$ & $7 \pi 1, r$. & $\uparrow \wedge$ & $\begin{array}{c}r V, \wedge \Lambda \\
(Y q, \cdot T)\end{array}$ & $\begin{array}{c}r, N) \\
(r, V \varepsilon)\end{array}$ & $\begin{array}{c}r \wedge, Y_{T} \\
\left(Y 9, Y_{0}\right)\end{array}$ & $\begin{array}{c}1 \varepsilon, 7 \pi \\
(10, V T)\end{array}$ & $\begin{array}{l}1 \cdot, \cdot 0 \\
(1 \cdot, V Y)\end{array}$ \\
\hline $\mathrm{C}_{\imath} \mathrm{H}_{r} \cdot \mathrm{Mn}_{r} \mathrm{~N}_{1} \mathrm{O}_{\imath}$ & $\begin{array}{c}\text { Pale } \\
\text { brown }\end{array}$ & $\begin{array}{l}\text { Dec } \\
\text { rTV }\end{array}$ & $7 \leq, \Gamma$. & 79 & $\begin{array}{l}, I V \\
(r), r \wedge)\end{array}$ & $\begin{array}{l}, 19 \\
(r, Y A)\end{array}$ & $\begin{array}{l}r r, q) \\
(r), q r)\end{array}$ & $\begin{array}{l}\mid \wedge, 91 \\
(1 \vee . \wedge 9)\end{array}$ & $\cdot, 7)$ \\
\hline $\mathrm{C}_{\curlywedge} \uparrow \mathrm{H} \backslash \wedge \mathrm{Fe}_{\curlyvee} \mathrm{N} \backslash \varepsilon \mathrm{O} 。$ & Brown & $\begin{array}{l}\text { Dec } \\
r . r\end{array}$ & $09 \wedge, 1$. & $\wedge \wedge$ & $\begin{array}{l}r, r u \\
(r, 1, r)\end{array}$ & $\begin{array}{l}r, \wedge \varepsilon \\
(r, \cdot r)\end{array}$ & $\begin{array}{l}r, \wedge . \\
(r r, V q)\end{array}$ & $\begin{array}{c}1 \wedge, 9 \wedge \\
(1 \wedge, 7 \vee)\end{array}$ & $1, \varepsilon$. \\
\hline $\mathrm{C}_{\imath} \mathrm{H}_{\curlywedge \wedge} \mathrm{Cor} \mathrm{N}_{\imath} \_\mathrm{O} 。$ & Blue & $\begin{array}{l}\text { Dec } \\
\text { TYq }\end{array}$ & $T \cdot \varepsilon, Y V$ & 71 & - & - & - & $\begin{array}{c}1 \Lambda, V T \\
(19,01)\end{array}$ & $\cdot, \mathrm{V}$ \\
\hline $\mathrm{C}_{\uparrow \uparrow} \mathrm{H}_{\curlywedge \wedge} \mathrm{Ni}_{\curlyvee} \mathrm{N}_{1} \mathrm{O}_{0}$ & Green & $\begin{array}{l}\text { Dec } \\
\text { TYY }\end{array}$ & $7 \cdot r, \vee 9$ & $V_{\top}$ & $\begin{array}{l}\Gamma \cdot, \lambda) \\
(r,, \lambda r)\end{array}$ & $\begin{array}{l}r, 90 \\
(r, \cdots)\end{array}$ & $\begin{array}{l}r r, \leq \wedge \\
(r r, \leq \wedge)\end{array}$ & $\begin{array}{c}19,0 \leqslant \\
(19, \leqslant \leqslant)\end{array}$ & $1, \cdot r$ \\
\hline $\mathrm{C}_{1} \mathrm{H}_{1} \mathrm{Cu}_{r} \mathrm{~N}_{1} \leqslant \mathrm{O}$ & Green & $\begin{array}{l}\text { Dec } \\
\text { ryo }\end{array}$ & $090, \leqslant \Lambda$ & $v \varepsilon$ & $\begin{array}{l}r, T_{0} \\
(r, Y V)\end{array}$ & $\begin{array}{l}r, 0 Y \\
(Y, V))\end{array}$ & $\begin{array}{l}r, q r \\
(r r, q r)\end{array}$ & $\begin{array}{c}(, \cdot r \\
(Y), r \leq)\end{array}$ & 1,10 \\
\hline $\mathrm{C}_{\uparrow} \uparrow \mathrm{H}_{\wedge} \mathrm{Zn}_{\uparrow} \mathrm{N}_{1} \mathrm{O}_{0}$ & $\begin{array}{c}\text { pale } \\
\text { yellow }\end{array}$ & $\begin{array}{l}\text { Dec } \\
r . r\end{array}$ & 718,19 & $\vee \wedge$ & - & - & - & $\begin{array}{c}1,1 V \\
(Y 1,19)\end{array}$ & • \\
\hline $\mathrm{C}_{\uparrow \uparrow} \mathrm{H}_{\curlywedge \wedge} \mathrm{Cd} \mathrm{N}_{\imath} \_\mathrm{O} 。$ & White & $\begin{array}{l}\text { Dec } \\
119\end{array}$ & $V ו 1, r r$ & 71 & - & - & - & $\begin{array}{c}r \cdot, v \checkmark \\
(r,, T)\end{array}$ & $\cdot, \leq r$ \\
\hline $\mathrm{C}_{\uparrow \uparrow} \mathrm{H}_{\curlywedge \wedge} \mathrm{Na} \mathrm{Ag}_{\curlyvee} \mathrm{N}_{1} \mathrm{O}_{0}$ & White & IN & $V \varepsilon \wedge, 1 Y$ & זיד & - & - & - & $\begin{array}{l}Y V, \wedge Y \\
(Y \wedge, \wedge \varepsilon)\end{array}$ & $\cdot, \Sigma T$ \\
\hline
\end{tabular}

$($ calc $)=$ calculated Dec $=$ decomposed .

\section{Molecular modelling}

rD molecular modelling of the proposed structure of the complexes was performed using CS Chem rD Ultra Molecular Modelling and Analysis Program [ [9]. It is an interactive graphics program that allows rapid structure building, geometry optimization with minimum energy and molecular display. It is well known program and has the ability to handle transition metal complexes [1·]. The correct stereochemistry was assured through the manipulation and modification of the molecular coordinates to obtain reasonable low energy molecular geometries.

\section{Results and Discussion \\ Chemistry}

The reaction of \&, $\_$-dipyridine with ethyl chloropropionate in mole ratio of $1: r$ gave the multidentate carboxylate ligands bis $(\mathrm{N}-$ carboxylatoethyl)- ₹,§-dipyridinium) $\mathrm{L}$, in moderate yield (Scheme 1). The ligand was characterised by elemental analysis (Table ( $(1)$ ), IR (Table ${ }^{r}$ ), UV-Vis (Table ( $\left.{ }^{\top}\right)$ ) spectroscopy. The neutral and di-electrolyte complexes of the general formula $\left[\mathrm{Cr} r(\mathrm{~L})\left(\mathrm{N}_{r}\right)_{\varepsilon}\right] \mathrm{Cl}_{r} . \mathrm{H}_{r} \mathrm{O}, \quad \mathrm{Nar}\left[\mathrm{Ag}_{r}(\mathrm{~L})\left(\mathrm{N}_{r}\right)_{\xi}\right] \cdot \mathrm{HrO}_{r} \mathrm{O}$ and $\left[\mathrm{M}_{r}(\mathrm{~L})\left(\mathrm{N}_{r}\right)_{\varepsilon}\right] . n \mathrm{HrO}_{r}$ (where $\mathrm{M}=\mathrm{Mn}, \mathrm{Fe}$, $\mathrm{Co}, \mathrm{Ni}, \mathrm{Cu}, \mathrm{Zn}$ and $\mathrm{Cd}, \mathrm{n}=\cdot, \mathrm{l}, \mathrm{r})$; were obtained (Scheme (1)). The complexes are airstable solids, soluble only in DMSO, and not soluble in other common organic solvents. The coordination geometries of the complexes were deduced from their spectra. The analytical data Table (1) agree well with the suggested formula. Conductivity measurements of the $\mathrm{Cr}(\mathrm{III})$ and $\operatorname{Ag}(\mathrm{I})$ mixed complexes lie in the $V^{\prime}, \leqslant 1$ and $V \wedge, \leqslant 7 \mathrm{~cm}^{\top} \Omega^{-1} \mathrm{~mol}^{-1}$ range, indicating their $1: r$ electrolytic behaviour, but non-electrolyte for other complexes [1'] Table ( 1 ). 

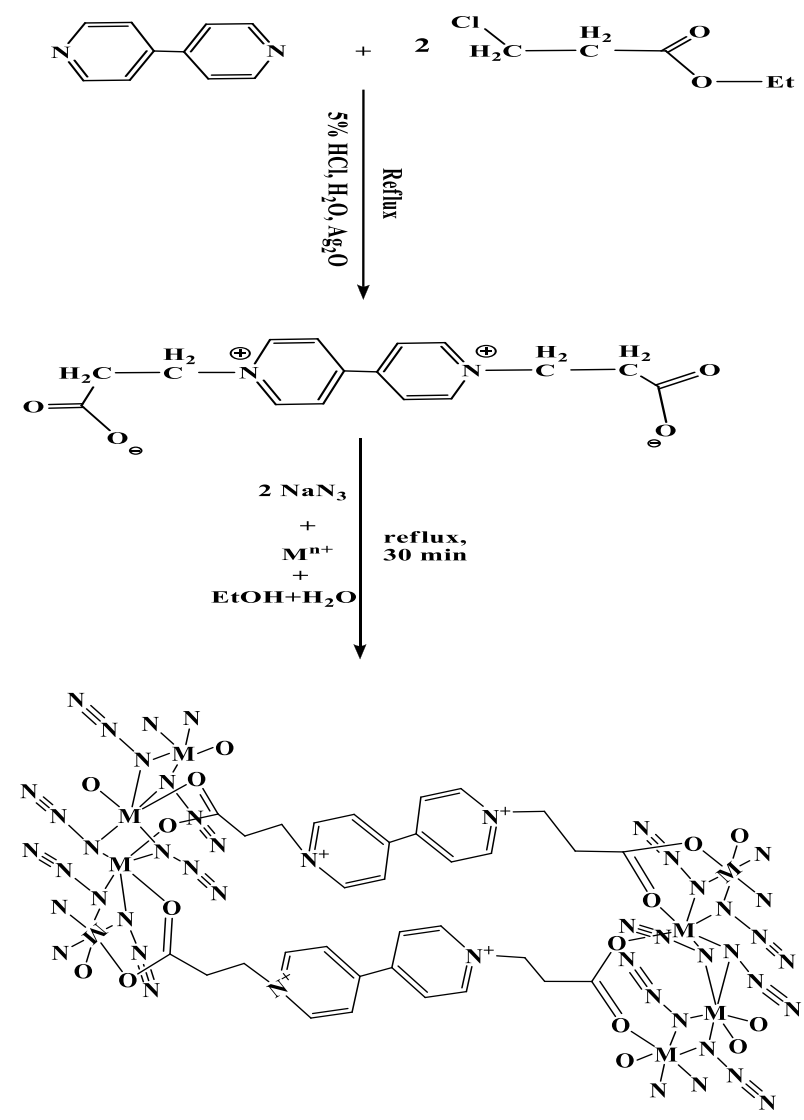

Where $\mathrm{M}=\mathrm{Cr}^{\mathrm{III}}, \mathrm{Mn}^{\mathrm{II}}, \mathrm{Fe}^{\mathrm{II}}, \mathrm{Co}^{\mathrm{II}}, \mathrm{Ni}^{\mathrm{II}}, \mathrm{Cu}^{\mathrm{II}}$, $\mathrm{Zn}^{\mathrm{II}}, \mathrm{Cd}^{\mathrm{II}}$, and $\mathrm{Ag}^{\mathrm{I}}$.

\section{Scheme (1) Synthesis route of ligand and the proposed polymeric complexes.}

\section{NMR and IR Spectra}

The NMR spectra of the ligand were consistent with the proposed structural formulae (see Experimental section). 'H NMR spectrum of the ligad (Figure 1) shows signals at $r, r)-r, r r\left(\left\{\mathrm{H}, \mathrm{t}, \mathrm{C} r, r^{-}-H\right)\right.$. This signal is appeared at up field due the attachment to electron withdrawing group, and therefore the $\left(-\mathrm{CH}_{r}\right)$ group is shielded and appeared at lower chemical shift. Chemical shift equivalent to $\varepsilon$ protons at $\varepsilon, \vee \backslash-\varepsilon, V r$ assigned to $C r$, r $-H$. This peak is shifted to downfield due to its attachment to the nitrogen atom, electron withdrawing group, and therefore the $(-\mathrm{CH} r)$ group is deshielded and appeared at higher chemical shift. The important infrared bands for the ligands and their complexes together with their assignments are listed in Table $(r)$. The IR spectrum of the ligand shows characteristic bands at $17 r r$ and $1 \leqslant 01$ assigned for vas $(\mathrm{COO})$ and $v_{\mathrm{s}}(\mathrm{COO})$, respectively [ $\left.{ }^{r}\right]$. Bands at $109 \mathrm{~V}$ and $10 \mathrm{VA} \mathrm{cm}^{-}$ ' are due to the $v(\mathrm{C}=\mathrm{N})$ and $v(\mathrm{C}=\mathrm{C})[r \leqslant]$, respectively. The IR spectra of the complexes exhibited ligand bands with the appropriate shifts and the $\mathrm{M}-\mathrm{O}$ and $\mathrm{M}-\mathrm{N}$ frequencies due to complex formation Table ( $r$ ). The IR spectra of the polymeric complexes display the $v_{a s}(C O O)$ stretching bands around 17.1 . I TY 1 $\mathrm{cm}^{-1}$ and $v_{\mathrm{s}}(\mathrm{COO})$ stretching bands around $1 \leq \ldots-$

I $\leqslant$ Tr $\mathrm{cm}^{-1}$, respectively. These bands were shifted to lower frequency compared with that in the free ligand, except for $\operatorname{Ag}(\mathrm{I})$ which shifted to higher frequency.

This can be attributed to delocalisation of metal electron density $(t r g)$ to the $\pi$-system of the ligand $[Y Y]$. The difference between $v_{\mathrm{as}}(\mathrm{COO})$ and $v_{\mathrm{s}}(\mathrm{COO})$ is characteristic for a bidentate coordination mode in which the carboxylato moiety adopts the syn-syn orientation except Ag (I) complex the carboxylato moiety adopts syn-anti mode [ $1 \%]$. The strong new bands located at $Y \cdot \leqslant$. rII $\leqslant \mathrm{cm}^{-1}$ and Irrq_irrq $\mathrm{cm}^{-1}$ were attributed to $v_{\mathrm{as}}(\mathrm{N} r)$ and $v_{\mathrm{s}}(\mathrm{Nr})$, respectively $[1 \leqslant]$. The six coordination is referred to the coordination of four azide group as $N(\mu), 1)$ fashion and the oxygen of carboxylate moieties to the metal atoms [10]. At lower frequency the complexes exhibited bands around $\Sigma \cdot \tau_{-} \varepsilon \wedge \tau^{-1} \mathrm{~cm}^{-1}$ may be assigned to $v(\mathrm{M}-$ $\mathrm{N})$, while the band at $\leqslant 9 \Lambda_{-}$ oरr $\mathrm{cm}^{-1}$ can be assigned to $v(\mathrm{M}-\mathrm{O})$ for the complexes [ $\left.{ }^{17}\right]$. The appearance of $v(\mathrm{M}-\mathrm{O})$ at frequency higher than that of $v(\mathrm{M}-\mathrm{N})$ due to the larger dipole moment change for $\mathrm{M}-\mathrm{O}$ compared to $\mathrm{M}-\mathrm{N}$, the $v(\mathrm{M}-\mathrm{O})$ usually appears at higher frequency than the $v(\mathrm{M}-\mathrm{N})$ band $[\mathrm{YV}]$. 
Table (r)

IR frequencies $\left(\mathrm{cm}^{-1}\right)$ of the compounds.

\begin{tabular}{|c|c|c|c|c|c|c|c|c|c|c|c|c|}
\hline complex & V0-H & $\mathrm{VCH}_{2}$ & $\mathrm{VN}$ & $v_{m} c 00$ & $\overline{\mathbf{v}}=\mathbf{N}$ & $\mathrm{y}, \mathrm{COO}$ & $\overline{60-H}$ & $\mathbf{v N}_{\mathrm{s}}$ & $\overline{\mathbf{V C}-\mathrm{N}}$ & vM-0 & WM-N & $\Delta^{\left(v_{-} y\right)}$ \\
\hline $\mathbf{L}$ & - & 2851 & - & 1082 & 1597 & 1458 & - & - & 1218 & - & & 174 \\
\hline$\left[\mathrm{Cr}_{2}(\mathrm{~L})\left(\mathrm{N}_{3}\right) \mathrm{H}_{1}\right] \mathrm{Cl}_{2} \mathrm{H}_{2} \mathrm{O}$ & 3414 & 2862 & $\begin{array}{l}2114 \\
2006\end{array}$ & 1620 & 1595 & 1420 & 1555 & 1335 & 1223 & $\begin{array}{l}536 \\
562\end{array}$ & $\begin{array}{l}424 \\
440\end{array}$ & 200 \\
\hline$\left[\mathrm{Mn}_{2}(\mathrm{~L})\left(\mathrm{N}_{3}\right)\right] 2 \mathrm{H}_{2} \mathrm{O}$ & 3387 & 2909 & 2066 & 1009 & 1572 & 1418 & 1522 & 1333 & 1223 & $\begin{array}{l}505 \\
561\end{array}$ & $\begin{array}{l}419 \\
434\end{array}$ & 191 \\
\hline$\left[\mathrm{Fe}_{2}(\mathrm{~L})\left(\mathrm{H}_{3}\right) \mathrm{H}\right] . \mathrm{H}_{2} \mathrm{O}$ & 3439 & 2841 & 2064 & 1617 & 1610 & 1400 & 1560 & 1346 & 1213 & $\begin{array}{l}586 \\
563\end{array}$ & $\begin{array}{l}406 \\
436\end{array}$ & 217 \\
\hline$\left[\mathrm{Co}(\mathrm{L})\left(\mathrm{N}_{3}\right)\right] \cdot \mathrm{H}_{2} \mathrm{O}$ & 3404 & 2914 & 200 & 1007 & 1570 & 1416 & 1533 & 1342 & 1221 & $\begin{array}{l}546 \\
565\end{array}$ & $\begin{array}{l}419 \\
457\end{array}$ & 191 \\
\hline$\left[\mathrm{Fi} 2(\mathrm{~L})\left(\mathrm{N}_{3}\right) \mathrm{H}_{\mathrm{H}} \mathrm{H}_{2} \mathrm{O}\right.$ & 3402 & 289 & $\begin{array}{l}2091 \\
2000\end{array}$ & 1605 & 1636 & 1416 & 1522 & 1344 & 1225 & $\begin{array}{l}498 \\
563\end{array}$ & 432 & 189 \\
\hline$\left[\mathrm{Cu}\left(\mathrm{L}^{5}\right)\left(\mathrm{N}_{3}\right)_{4}\right]$ & 3422 & 2828 & 2041 & 1628 & 1593 & 1412 & 1485 & 1369 & 1223 & $\begin{array}{l}901 \\
582 \\
574\end{array}$ & $\begin{array}{l}440 \\
474\end{array}$ & 216 \\
\hline$\left[\mathrm{Zn}_{2}(\mathrm{~L})\left(\mathrm{N}_{3}\right)_{4}\right] \mathrm{H}_{2} \mathrm{O}$ & 3416 & 2846 & 2085 & 1611 & 1533 & 1416 & 1491 & 1344 & 1219 & $\begin{array}{l}536 \\
567\end{array}$ & $\begin{array}{l}422 \\
486\end{array}$ & 195 \\
\hline$\left[\mathrm{Cd}(\mathrm{L})\left(\mathrm{H}_{3}\right)\right] \cdot \mathrm{H}_{2} \mathrm{O}$ & 3418 & 2833 & 2000 & 1001 & 1638 & 1418 & 1537 & 1329 & 1221 & $\begin{array}{l}500 \\
565\end{array}$ & $\begin{array}{l}444 \\
463\end{array}$ & 183 \\
\hline 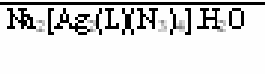 & 3449 & 2824 & 2045 & 1628 & 1593 & 1462 & 1482 & 1361 & 1227 & $\begin{array}{l}501 \\
583\end{array}$ & $\begin{array}{l}478 \\
483\end{array}$ & 166 \\
\hline
\end{tabular}

\section{Mass Spectra}

The mass spectrum of the ligand was consistent with the proposed structural formulae (see Experimental section). The positive ion MALDI mass spectra for several complexes were reported. The mass spectrum of $[\mathrm{Cor}(\mathrm{L})(\mathrm{Nr}) \varepsilon] . \mathrm{HrO}_{r} \mathrm{showed}$ several peaks corresponding to successive fragmentation of the molecule. The complex showed peak at

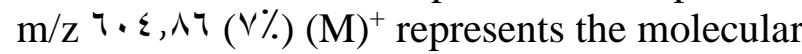
ion peak of the complex. Other distinct peaks were observed in the mass spectrum at $\mathrm{m} / \mathrm{z}$

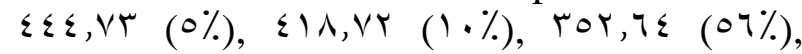

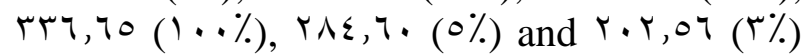
can be assigned to the

$\left(\mathrm{M}-\left(r^{r} \mathrm{~N}_{r}+{ }^{r} \mathrm{CO}+\mathrm{CH}_{\varepsilon}+\mathrm{N}_{r} \mathrm{H}_{\varepsilon}\right)\right)^{+}$,

$\left(\mathrm{M}-\left({ }^{r} \mathrm{~N}_{r}+{ }^{r} \mathrm{CO}+\mathrm{CH} s+\mathrm{N}_{r} \mathrm{H}_{\imath}+\mathrm{CN}\right)^{+}\right.$,

$\left(\mathrm{M}-\left({ }^{r} \mathrm{~N}_{r}+{ }^{r} \mathrm{CO}+\mathrm{CH} \varepsilon+\mathrm{N} r \mathrm{H}_{\varepsilon}+{ }^{r} \mathrm{CN}+\mathrm{C} r \mathrm{H} \varepsilon\right)^{+}\right.$and $\left(\mathrm{M}-\left(r^{r} \mathrm{~N}_{r}+{ }^{r} \mathrm{CO}+\mathrm{CH} \varepsilon+\mathrm{N} r \mathrm{H}_{\varepsilon}+{ }^{r} \mathrm{CN}+\mathrm{C} r \mathrm{H} \varepsilon \mathrm{O}\right)^{+}\right.$,

$\left(\mathrm{M}-\left({ }^{r} \mathrm{~N}_{r}+{ }^{r} \mathrm{CO}+\mathrm{CH}_{\varepsilon}+\mathrm{N}_{r} \mathrm{H}_{\varepsilon}+{ }^{r} \mathrm{CN}+\mathrm{C}_{r} \mathrm{H}_{\varepsilon} \mathrm{O}+\right.\right.$

$\left.\mathrm{C}_{r} \mathrm{H}_{r}+\mathrm{CN}\right)^{+}$,

$\left(\mathrm{M}-\left({ }^{r} \mathrm{~N}_{r}+{ }^{r} \mathrm{CO}+\mathrm{CH}_{\varepsilon}+\mathrm{N}_{r} \mathrm{H}_{\varepsilon}+{ }^{r} \mathrm{CN}+\right.\right.$

$\left.\mathrm{C}_{r} \mathrm{H}_{\varepsilon} \mathrm{O}+\mathrm{C}_{r} \mathrm{H}_{r}+\mathrm{CN}+\mathrm{N}_{\imath}+\mathrm{CN}\right)^{+}$fragments, respectively. The spectrum of $\left[\mathrm{Zn}_{r}(\mathrm{~L})\left(\mathrm{N}_{r}\right)_{\varepsilon}\right] \cdot \mathrm{H}_{r} \mathrm{O}$, displayed peak at $\mathrm{m} / \mathrm{z}=\mathrm{T} / \mathrm{V}$, or $(\mathrm{M})+(\mathrm{V} \%)$ represents the molecular ion peak of the complex. Other distinct peaks were observed in the mass spectrum at $\mathrm{m} / \mathrm{z} 0 \leqslant 0, \leqslant r(r \%)$, $\varepsilon .0, \ldots(r \%), r r r, q \wedge(\wedge \%), r r q, . q(r \leq \%)$, $\curlywedge \wedge \wedge, 1 \wedge(\Sigma \vee \%)$ and $|0 \vee,| \wedge(1 \ldots \%)$ can be assigned to the $(\mathrm{M}-(\mathrm{Nr}+\mathrm{NrO}))^{+}, \quad(\mathrm{M}-$ $\left({ }^{r} \mathrm{Nr}_{r}+\mathrm{CO}+\mathrm{CH}_{r} \mathrm{CH}_{r}\right)^{+}, \quad\left(\mathrm{M}-\left(\mathrm{CH}_{r} \mathrm{CH}_{r}+\mathrm{CO}_{r}\right)^{+}\right.$ and $\left(\mathrm{M}-\left({ }^{r} \mathrm{CN}+{ }^{r} \mathrm{CH}=\mathrm{CH}\right)\right)^{+}$, $\left(\mathrm{M}-\left({ }^{r} \mathrm{CN}+{ }^{r} \mathrm{CH}=\mathrm{CH}+\mathrm{C}+\mathrm{H}_{0}\right)\right)^{+}$and $\left(\mathrm{M}-\left({ }^{r} \mathrm{CN}+{ }^{r} \mathrm{CH}=\mathrm{CH}+\mathrm{C} r \mathrm{H} \circ+\mathrm{N}-\mathrm{OH}\right)\right)^{+}$

fragments, respectively. These results are similar to those of analogous complexes reported earlier by others [ $1 \wedge]$.

\section{Electronic spectra and magnetic moment measurements}

The UV-Vis spectrum of L (Fig. $(r)$ ) exhibits a high intense absorption peak at r $\vee 9 \mathrm{~nm}$, assigned to the overlapping peaks of $\pi \rightarrow \pi^{*}$ and $\mathrm{n} \rightarrow \pi^{*}$ [19]. The electronic spectrum of the $\mathrm{Cr}$ (III) complex shows a high intense peaks at r $7 r \mathrm{~nm}$ due to intra-ligand. The low intense peaks at $\mathrm{V} 07$ and $\leqslant 7 \mathrm{Vm}$ were attributed to the ${ }^{\wedge} \mathrm{Arg} \rightarrow{ }^{\varepsilon} \mathrm{T} r \mathrm{~g}^{(\mathrm{F})}(v)$ ) and ${ }^{\varepsilon} \mathrm{A} r \mathrm{~g} \rightarrow{ }^{\varepsilon} \mathrm{T} / \mathrm{g}^{(\mathrm{F})}$ (Vr) transitions, respectively. These bands attributed to the spin allowed d-d transitions, indicating an octahedral geometry around the $\mathrm{Cr}(\mathrm{III})$ atom $[r \cdot]$. The electronic spectrum of the Mn(II) complex shows three peaks at $r \checkmark \wedge \mathrm{nm}$ due to intra-ligand, rчr $\mathrm{nm}$ due to charge transfer and $T \leqslant r \mathrm{~nm}$ assigned to ${ }^{\top} \mathrm{A}, \mathrm{g} \rightarrow{ }^{{ }^{k} \mathrm{~T}}, \mathrm{~g}^{(\mathrm{G})}$ transition [ [ $\left.{ }^{\prime}\right)$ ]. Electronic data of other complexes displayed peaks 
confirming octahedral geometries around metal atoms Table $(r)$. The $\mathrm{d}^{\prime}$ complexes exhibited bands at $r>\tau$, r $r o$ and $r \tau \leqslant \mathrm{nm}$, respectively which assigned to the ligand field for $\mathrm{Zn}(\mathrm{II}), \mathrm{Cd}(\mathrm{II})$ and $\mathrm{Ag}(\mathrm{I})$ complexes, respectively. The room temperature magnetic moments of the complexes are reported in Table ( $r)$. Complexes show magnetic moments in the range $, V q_{-}, \cdot r$ BM. The very low observed moments are allowed us to conclude safely that the complexes are antiferromagnetic $[r r]$.

Table (")

Magnetic moment, u.v-vis spectral data in DMSO solutions and total minimisation energy.

\begin{tabular}{|c|c|c|c|c|c|c|}
\hline Compound & $\begin{array}{c}\mu_{e f f} B M \\
\text { per atom }\end{array}$ & $\begin{array}{c}\text { Band } \\
\text { Position } \\
\lambda_{n m} \\
\end{array}$ & $\begin{array}{c}\text { Wave } \\
\text { number } \\
\left(\mathrm{cm}^{-1}\right) \\
\end{array}$ & $\begin{array}{c}\text { Extinction } \\
\text { coefficient } \\
\varepsilon_{\max }\left(\mathrm{dm}^{r} \mathrm{~mol}^{-1} \mathrm{~cm}^{-1}\right) \\
\end{array}$ & Assignment & $\begin{array}{c}\text { Total } \\
\text { energy } \\
\text { Kcal/mol } \\
\end{array}$ \\
\hline $\mathrm{L}$ & - & rVq & $r O \Lambda \leq r$ & $Y \cdot \leq T$ & $\mathrm{n} \rightarrow \pi^{*}$ and $\pi^{*} \rightarrow \pi^{*}$ & $-1 \Gamma \wedge, 110 \leq$ \\
\hline$[\mathrm{Cr} r(\mathrm{~L})(\mathrm{N} r) \leqslant] \mathrm{Cl}_{r} \cdot \mathrm{H} r \mathrm{O}$ & $r, \varepsilon \leqslant$ & $\begin{array}{l}\text { ROT } \\
\text { STV }\end{array}$ & 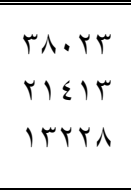 & $\begin{array}{c}1 \times 10 \\
\varepsilon \\
1\end{array}$ & $\begin{array}{c}\text { Intra-ligand } \\
{ }^{\varepsilon} \mathrm{A}_{r g} \rightarrow{ }^{\varepsilon} \mathrm{T}_{r g}\left(v_{\curlywedge}\right) \\
{ }^{\varepsilon} \mathrm{A} r \mathrm{~g}^{(\mathrm{F})} \rightarrow{ }^{\varepsilon} \mathrm{T} \mathrm{g} \\
\left(v_{r}\right)\end{array}$ & $1 \leq \wedge, \wedge 90$ \\
\hline$\left[\mathrm{Mn}_{r}(\mathrm{~L})\left(\mathrm{N}_{r}\right) \varepsilon\right] \cdot{ }^{r} \mathrm{H}_{r} \mathrm{O}$ & $r, r$ & $\begin{array}{l}r 4 \lambda \\
r T 4 \\
r \leq r\end{array}$ & $\begin{array}{l}\text { TVMIT } \\
\text { YVTYE } \\
\text { 1000T }\end{array}$ & $\begin{array}{c}40 . \\
41 \\
1\end{array}$ & $\begin{array}{l}\text { Intra-ligand } \\
\text { C.T } \\
{ }^{\top} \mathrm{A}, \mathrm{g} \rightarrow{ }^{\mathfrak{\varepsilon}} \mathrm{T}, \mathrm{g}^{(\mathrm{G})}\end{array}$ & $1 \leq 9, r \vee \vee \neg$ \\
\hline$\left[\mathrm{Fe}_{r}(\mathrm{~L})\left(\mathrm{N}_{r}\right)_{\varepsilon}\right] \cdot \mathrm{H}_{r} \mathrm{O}$ & $\cdot, \vee \vee 9$ & $\begin{array}{l}\text { TVT } \\
\text { TTY } \\
\text { ONT }\end{array}$ & $\begin{array}{l}\text { MTVTE } \\
\text { YVTYE } \\
\text { IV.T0 }\end{array}$ & $\begin{array}{l}r \mid \leq \varepsilon \\
r \cdot T \\
r\end{array}$ & $\begin{array}{c}\text { L.F } \\
\text { C.T } \\
{ }^{\circ} \mathrm{T} r g \rightarrow{ }^{\circ} \mathrm{Eg}\end{array}$ & IYA,rrTY \\
\hline$[\mathrm{Cor}(\mathrm{L})(\mathrm{N} r) \xi] . \mathrm{HrO}_{r} \mathrm{O}$ & $1, V V$ & $\begin{array}{l}T V . \\
r \leq T \\
T H T \\
T R V\end{array}$ & $\begin{array}{l}r V \cdot r V \\
r \wedge 9 \cdot 1 \\
10 V 9 \wedge \\
1 \leq V V \mid\end{array}$ & $\begin{array}{l}+r t \\
\text { Irq } \\
\text { RT }\end{array}$ & $\begin{array}{c}\text { L.F } \\
\text { C.T } \\
{ }^{\varepsilon} \mathrm{T}, \mathrm{g}^{(\mathrm{F})} \rightarrow{ }^{\varepsilon} \mathrm{A} r \mathrm{~g}^{(\mathrm{F})} \\
{ }^{\mathrm{T}} \mathrm{T}, \mathrm{g}^{(\mathrm{F})} \rightarrow{ }^{\varepsilon} \mathrm{A} \mathrm{r} \mathrm{g}^{(\mathrm{F})}\end{array}$ & $r \cdot V, 001 \leq$ \\
\hline$\left[\mathrm{Ni}_{r}(\mathrm{~L})\left(\mathrm{N}_{r}\right)_{\varepsilon}\right] \cdot \mathrm{H}_{r} \mathrm{O}$ & 1,00 & 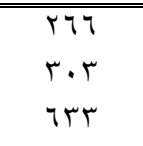 & $\begin{array}{l}\text { rvogs } \\
\text { lovas }\end{array}$ & $\begin{array}{l}\text { VON } \\
\text { ITE } \\
\text { Or }\end{array}$ & $\begin{array}{c}\text { L.F } \\
\text { C.T } \\
{ }^{\top} \mathrm{T} \text { rg } \rightarrow{ }^{r} \mathrm{~T}, \mathrm{~g}^{(\mathrm{F})}\end{array}$ & $7 \leq 9,0 \leq 70$ \\
\hline$\left[\mathrm{Cu}_{r}(\mathrm{~L})\left(\mathrm{N}_{r}\right)_{\varepsilon}\right]$ & $1, \cdot 1$ & $\begin{array}{l}411 \\
711\end{array}$ & 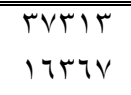 & $\begin{array}{l}1 \% 0 . \\
0 .\end{array}$ & $\begin{array}{c}\text { L.F } \\
{ }^{r} \mathrm{~B}^{\prime} \mathrm{g} \rightarrow{ }^{r} \mathrm{~B}_{r g} \mathrm{~g}\end{array}$ & $10 ., . \leq 94$ \\
\hline$\left[\mathrm{Zn}_{r}(\mathrm{~L})\left(\mathrm{N}_{r}\right)_{\varepsilon}\right] \cdot \mathrm{H}_{r} \mathrm{O}$ & - & Y77 & rvo9s & $1 \leq \varepsilon r$ & L.F & ITY,Y970 \\
\hline$\left[\mathrm{CCd}_{r}(\mathrm{~L})\left(\mathrm{N}_{r}\right)_{\xi}\right] \cdot \mathrm{H}_{r} \mathrm{O}$ & - & r70 & TVVYY & VYT & $\overline{\text { L.F }}$ & $109,9 \vee r 9$ \\
\hline $\begin{array}{c}\left.\operatorname{Nar}_{r} \operatorname{Ag}_{r}(\mathrm{~L})\left(\mathrm{N}_{r}\right)_{\xi}\right] \cdot \mathrm{H}_{r} \\
\mathrm{O}\end{array}$ & - & rTs & rVAvq & qTo. & L.F & Ir.,... \\
\hline
\end{tabular}

rD molecular modelling and analysis of bonding modes

Molecular mechanics attempts to reproduce molecular geometries, energies and other features by adjusting bond length, bond angles and torsion angles to equilibrium values that are dependent on the hybridization of an atom and its bonding scheme. In order to obtain estimates of structural details of these complexes and in view the six-coordination of all the complexes, we have optimised the molecular structure of the ligands and their M-complexes and we have included $\left[\mathrm{Nir}(\mathrm{L})(\mathrm{Nr})_{\varepsilon}\right] . \mathrm{HrO}_{r} \mathrm{O}$ as a representative compound. The detail of bond lengths and bond angles per the rD molecular structure is given in Table ₹. Energy minimization was repeated several times to find the global 
Journal of Al-Nahrain University Science

minimum [ [ $r)]$. The energy minimization value for octahedral and without restricting the structure for the prepared M-compounds are presented in Table $(\varepsilon)$. The molecular modelling for the modulated $\mathrm{Ni}$ (II)-complex (Fig. ( $~()$ and Table ( $\varepsilon)$ ) shows the bond lengths bond angles around $\mathrm{Ni}$ atom, indicating a distorted octahedral geometry around $\mathrm{Ni}(\mathrm{II})$ ion $[Y \varepsilon]$, and thus the proposed structure of the $\mathrm{Ni}(\mathrm{II})$-complexes are acceptable.

Table ( $\varepsilon)$

The calculated bond length and bond angle of [Nir( $\left.\left.L^{r}\right)(N) \leq\right] . H$ r $O$.

\begin{tabular}{|c|c|c|c|}
\hline Type of Bond & Bond length $\left(A^{\circ}\right)$ & Type of Bond & Bond angle( $\left(^{\circ}\right)$ \\
\hline $\mathrm{Ni} /-\mathrm{N}_{1}$ & $1, \wedge Y \tau$ & $\mathrm{O}_{1}-\mathrm{Ni} \backslash-\mathrm{N}$, & $1 \wedge, \ldots$ \\
\hline $\mathrm{Ni} /-\mathrm{Nr}$ & $1, \wedge Y T$ & $\mathrm{O}_{1}-\mathrm{Ni} /-\mathrm{N}_{r}$ & 19,994 \\
\hline $\mathrm{Ni} /-\mathrm{N} \varepsilon$ & $1, \wedge r \wedge$ & $\mathrm{O}_{1}-\mathrm{Ni} /-\mathrm{Or}_{\mathrm{r}}$ & $\wedge 9,99 \vee$ \\
\hline $\mathrm{Ni} /-\mathrm{N}_{r}$ & $1, \wedge Y T$ & $\mathrm{~N} \backslash-\mathrm{Ni} /-\mathrm{Or}$ & $9 \cdot, \ldots \varepsilon$ \\
\hline $\mathrm{Ni}^{2}-\mathrm{Or}_{\mathrm{r}}$ & $1, \vee \vee 9$. & $\mathrm{Nr}-\mathrm{Ni} /-\mathrm{Or}$ & $V \leqslant, 1 \cdot r$ \\
\hline $\mathrm{C}_{1}-\mathrm{O}_{1}$ & $1, \varepsilon \cdot r$ & $\mathrm{~N}_{\varepsilon}-\mathrm{Ni}_{1}-\mathrm{N}_{r}$ & $T \varepsilon, 7 \cdot V$ \\
\hline $\mathrm{Nr}-\mathrm{N}_{0}$ & $1, \Gamma 01$ & $\mathrm{~N}_{\varepsilon-}-\mathrm{Ni}_{1}-\mathrm{O} r$ & ITr,VTV \\
\hline \multirow[t]{2}{*}{$\mathrm{N}_{\varepsilon-\mathrm{N}_{\imath}}$} & $1, \pi 01$ & $\mathrm{Ni} /-\mathrm{N} r-\mathrm{Nir}$ & $9 \cdot \ldots$ \\
\hline & & $\mathrm{Ni}_{1-\mathrm{N}_{\varepsilon}-\mathrm{Ni}{ }_{r}}$ & $\Lambda 9,7 \leqslant Y$ \\
\hline
\end{tabular}

\section{Conclusion}

In this paper, we have explored the synthesis and coordination chemistry of some carboxylato-azido metal-complexes derived from the polydentate ligand L. The ligand behaves as a neutral species upon complexation with the involvement of the nitrogen atoms of the azido groups in coordination for all complexes. The magnetic susceptibilities and electronic spectra of the complexes indicated that they are antiferrromagnetic with octahedral geometry about metal atoms.

\section{References}

['] Ren P., Shi W., Cheng P., Synthesis and Characterization of Three-Dimensional $r_{d}-r_{d}$ and $r_{d}-\varepsilon f$ Heterometallic Coordination Polymers with High Thermal Stability, Cryst. Growth Des., ^, ।.9 _ $_{-}$ 1.99, r...

[r] Du M., Bu X. H., Guo Y. M., Ribas J., Ligand Design for Alkali-Metal-Templated Self-Assembly of Unique High-Nuclearity CuII Aggregates with Diverse Coordination Cage Units: Crystal
Structures and Properties, Eur. J., '•, $1 T \leqslant 0_{-} \mid r 0 \leqslant, T_{\ldots} .$.

[ץ] Wang X. Y., Wang Z. M., Gao S., Constructing magnetic molecular solids by employing three-atom ligands as bridges, Chem. Comm., $\left.{ }^{\circ}, r \wedge\right)-r q \leqslant, r \cdots \wedge$.

[๕] Prasad T. K., Rajasekharan M. V., Solvent Dependent Crystallization of Isomeric Chain Coordination Polymers in the Ce-Zn/Cd-dipic System, Cryst. Growth Des., $\wedge, 1 r \leq r_{-} \mid$ror, r...

[०] Enoki T., Miyazaki A., Synthesis Strategies and Chemistry of Nonsymmetrically Substituted Tetrachalcogenafulvalenes, Chem. Rev., $1 \cdot \leq, 0 \leqslant \leqslant q \_0 \leqslant V V, r \cdots \leqslant$.

[7] Amo-Ochoa P., Castillo O., Alexandre S. S., Welte, L.; de Pablo P. J., RodriguezTapiador M. I., Gomez- Herrero J., Zamora F., Synthesis of Designed Conductive One-Dimensional Coordination Polymers of $\mathrm{Ni}(\mathrm{II})$ with $\mathrm{r}_{\text {- }}$ Mercaptopurine and 7 -Thioguanine, Inorg.

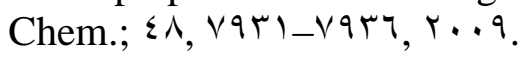

[`] Wang Y. Q., Zhang J. Y., Jia Q. X., Gao E. Q., Liu C. M., Unprecedented Self- 
Catenated Eight-Connected Network Based on Novel Azide-Bridged Tetramanganese (II) Clusters, Inorg.

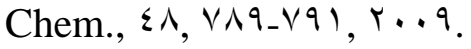

[^] Zhou X. H., Peng Y. H., Du X. D., Wang C. F., Zuo J. L., You X. Z., New rd- $-\varepsilon f$ Heterometallic Coordination Polymers Based on Pyrazole-Bridged CuIILnIII Dinuclear Units and Sulfate Anions: Syntheses, Structures, and Magnetic Properties, Cryst. Growth Des., १, I. r $\Lambda_{-}$ 1. ro, r...

[9] CS Chem rD Ultra Molecular Modelling and Analysis, Cambridge, www. Cambridge soft. com.

[1·] Maurya R. C., Rajput S., Oxovanadium (IV) complexes of bioinorganic and medicinal relevance: Synthesis, characterization and rD molecular modeling and analysis of some oxovanadium(IV) complexes involving the $\mathrm{O}$, N-donor environment of pyrazolonebased sulfa drug Schiff bases, J. Molecular Structure, $\vee 9 \leqslant, r \leqslant-r \leqslant, r \cdots\urcorner$.

[1'] Geary W.J., The use of conductivity measurements in organic solvents for the characterisation of coordination

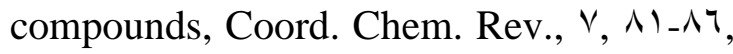
19V1.

[I ${ }^{Y}$ ] Livingston S. E., Mayfield J. H., Moorse D.S., Thio Derivatives of P-Diketones and their Metal Chelates, Aust. J. Chem., rA(r), YOT I_YOYV, 19VO.

[1r] Li-Fang S., Chun-Hong J., Cheng-Li J., Jian Z., Li-Xian S., Fen X., Wan-Sheng Y., Zhong-G. W. and Ji-Jun Z., Two New Metal-Organic Frameworks with Mixed Ligands of Carboxylate and Bipyridine: Synthesis, Crystal Structure, and Sensing for Methanol, Cryst. Growth \& Des.,

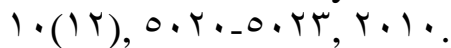

[ [ ] Sandip M., Bappaditya G., Yo S. and Partha S. M., Synthesis, Structures, and magnetic behaviour of a series of $\mathrm{Cu}$ (II) azide polymers of $\mathrm{Cu}$ ₹ building clusters and isolation of a new hemiaminal ether as the metal complex, Inorg. Chem., $\bullet$,

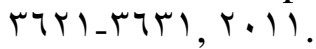

[10] El-Sonbati, A. Z., El-bindary A. A., Al-Sarawy, A. A., Stereochemistry of new nitrogen containing heterocyclic aldehyde.
IX. Spectroscopic studies on novel mixedligand complexes of $\mathrm{Rh}(\mathrm{III})$, Spectro chem Acta Part A, ON(I r), rVYI, r...

[17] Raman N., Esther S., Thangaraj C., A new Mannich base and its transition metal (II) complexes-Synthesis, structural characterization and electrochemical study,

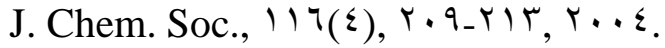

[IV] Nakamoto K. and Ohkaku N., Metal isotope effect on metal-ligand vibrations. VI. Metal complexes of $\Lambda_{-}$ hydroxyquinoline, Inorg. Chem., ' •, ২৭^_ A. $1,19 \times 1$.

[1^] Mevellec F., Collet S., Deniaud D., Reliquet A., Meslin J. C., Perkin Trans., Synthesis of new chiral and nonchiral $\mathrm{N} r O r^{r}$ and NrSr tetradentate ligands and their metal complexes, J. Chem. Soc., ',

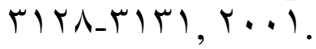

[19] Kemp W., "Organic Spectroscopy". rnd, Edition., 1 $9 \wedge \mathrm{v}$.

[ץ.] Mohamad J. Al-Jeboori, Ahlam J. AbdulGhani and Ahmed J. Al-Karawi, Synthesis and structural studies of new Mannich base ligands and their metal complexes, Transition Met.Chem, rr, q ro_qr., r...

[r)] Mohamad J. Al-Jeboori, Amar H. AlDujaili and Alyaa E. Al-Janabi, Coordination of carbonyl oxygen in the complexes of polymeric-N-crotonyl- $\mathrm{r}_{-}$ hydroxyphenylazo- methine, Transition Met, Chem., r\&, 1.9_ $11 r, r \ldots q$.

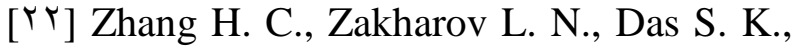
Hetu M. M., Rheingold A. L., Carboxyester hydrolysis promoted by $\mathrm{Cu}$ (II) complexes of pyridyl-amine carboxylate-pendant ligands, Inorg.Chem. Acta, $Y 7 \cdot(0),|79|-\mid V \cdot 1, r \cdots V$.

$\left[{ }^{r}\right]$ ] Mishra A. P., Mishra R. K., Shrivastava S. P., Structural and antimicrobial studies of coordination compounds of VO(II), $\mathrm{Co}(\mathrm{II}), \mathrm{Ni}(\mathrm{II})$ and $\mathrm{Cu}(\mathrm{II})$ with some Schiff bases involving $r$-amino- $\varepsilon$-chlorophenol, J. Serb. Chem. Soc., $V \leqslant(0)$, orr_oro, r... 9 .

[r£] Colak A. T., Irez G., Mutlu H., Hökelek T., Caylak N., A Co(III) complex with a tridentate amine-imine-oxime ligand from $1, r, r, \varepsilon$-tetrahydroquinazoline: synthesis, crystal structure, spectroscopic and thermal 
characterization, J. Coord. Chem., Ir ( 7 ), 1... $0_{-} \mid \cdot 1 \leq, r_{\ldots} .9$.

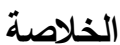

تضمن البحث تحضير ليكاند جديد متعدد السن

bis(N-carboxylatomethyl)- ¿ ، من تفاعل ع-ع-ثنائي بيريدين مع اثيل كلورو بروبيونت.

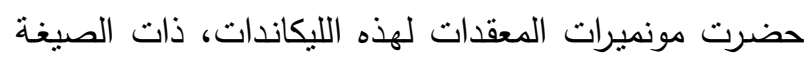
العامة $\left[\mathrm{M}_{r}(\mathrm{~L})\left(\mathrm{N}_{r}\right)_{\xi}\right] \cdot \mathrm{nH}_{r} \mathrm{O}, \mathrm{Na}_{r}\left[\mathrm{Ag}_{r}(\mathrm{I})(\mathrm{L})\left(\mathrm{N}_{r}\right)_{\xi}\right] \mathrm{H}_{r} \mathrm{O}$ (M = Mn(II), (II), Co(II), Ni(II), Cu(II), حيث

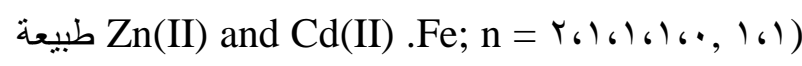
الارتباط والاشكال الهندسية لهذه المعقدات شخصت بواسطة طيف الاتشعة تحت الحمراء، طيف الاشعة فوق البنفسجيةالمرئية، الرنين النووي المغناطيسي، طيف الكتلة، قياسات

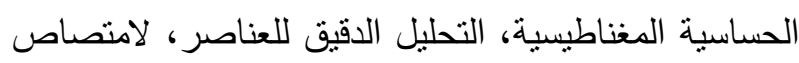

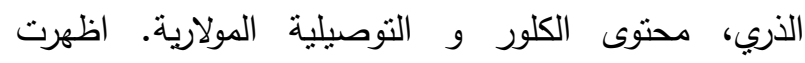
الدراسات شكل ثماني السطوح حول المراكز الفلزية للمعقدات ويحصل الارتباط من خلال مجاميع الازايد والكاربوكسيلات. التراكيب الجزيئية للمعقدات قد حددت بواسطة CS Chem rD Ultra Molecular Modelling and Analysis Program 